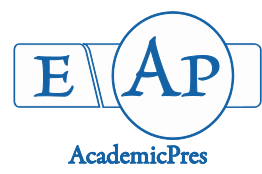

\title{
Effects of Varying Levels of Dried Poultry Droppings on Haematology, Microbial Properties and Nutrient Utilization of Clarias gariepinus
}

\author{
Adebola Oluyinka AJIBOYE ${ }^{1 *}$, Abimbola Adetokunbo OWOSENI², \\ Funmilola AJANI ${ }^{3}$ \\ ${ }^{1}$ Bowen University, Faculty of Agriculture, Department of Animal Science and Fisheries Management, Iwo, Osun State, \\ Nigeria; debron2005@yahoo.com (*correspondingauthor) \\ ${ }^{2}$ Bowen University, Faculty of Science and Science Education, Department of Biological Sciences, Iwo, Osun State, \\ Nigeria; abimbolaowoseni@gmail.com \\ ${ }^{3}$ University of Ibadan, Faculty of Natural Renewable Resources, Department of Wildlife and Ecotourism Management, Ibadan, Oyo State, \\ Nigeria; funmilolajani@yahoo.com
}

\begin{abstract}
Effects of varying levels of Dried Poultry Droppings fed Clarias gariepinus were investigated for 84 days. The fish meal was partially and completely replaced by dried poultry droppings at $0 \%, 25 \%, 50 \%, 75 \%$ and $100 \%$ inclusions and was allotted T1, T2, T3, T4 and T5 respectively. Investigation conducted on the occurrence of microbes in the fish feeds revealed that T5 varied significantly $(\mathrm{p}<0.05)$ in Total Viable Count (TVC) $\left(13.0 \times 10^{5} \mathrm{cfu} / \mathrm{g}\right)$ and Total Fungal Count (TFC) $\left(0.70 \times 10^{5} \mathrm{cfu} / \mathrm{g}\right)$ respectively. The microbial properties of the fish carcass showed that T5 was significantly higher $(\mathrm{p}<0.05)$ in TVC $\left(2.72 \times 10^{5} \mathrm{cfu} / \mathrm{g}\right)$, TCC $\left(0.33 \times 10^{5} \mathrm{cfu} / \mathrm{g}\right)$, while T3 and T5 were significantly higher in TFC $\left(0.20 \times 10^{3} \mathrm{cfu} / \mathrm{g}\right)$. The haematological parameters of Clarias gariepinus fed diet substituted with dried poultry droppings showed that Packed Cell Volume (PCV) $(43.00 \mathrm{~g} / \mathrm{l})$ and Haemoglobin $(\mathrm{Hb})(11.23 \mathrm{~g} / \mathrm{l})$ of $\mathrm{T} 1$ were significantly higher $(\mathrm{p}<0.05)$ than other treatments. The values of Red Blood Cell $(\mathrm{RBC})$ revealed that $\mathrm{T} 2\left(3.77 \times 10^{6} \mathrm{~mm}^{3}\right)$ was significantly different $(\mathrm{p}<0.05)$ compared to other treatments. The growth performance showed that T2 varied significantly $(p<0.05)$ in Mean Weight Gain (MWG) (29.33 g) and Feed Conversion Ratio (FCR) (0.09). The findings of the current study imply that feed microbes affected the haematological parameters of the fish and equally suppressed the growth of the fish.
\end{abstract}

Keywords: dried poultry droppings, growth parameters, haematological parameters, proximate compositions

\section{Introduction}

In an attempt to sustain aquaculture, fish farmers had resulted to fish culture alongside with other farming systems (fish farming cum poultry, piggery, duck, rice etc.) with the hope of providing alternative feed stuffs to substitute fish meal which cannot be afforded by many fish farmers. High cost of fish meal has resulted to farmers using unconventional feedstuffs that could not achieve maximum growth required by fish. Various researchers had investigated into different alternative protein feedstuffs that can be used to substitute fish meal and reduce the cost of feed formulation (Wang et al., 2006; Antolovic et al., 2012; Jatta, 2013; Kushwaha, 2013).

An integral part of aquaculture is majorly determined by fish feed and is an important factor to its development, considering that feed forms as much as $60 \%$ of the operational cost in fish farming (Ayinla and Bekibele, 1992). The major and the only affordable animal protein in many developing countries is provided by fish and is very expensive for ordinary or low income earners (Jatta, 2013).

Formulation of low-cost balanced diet using locally available agro industry by-products is needed for commercial culture of fish (Kushwaha, 2013). One of the challenges faced by aquaculture in feed formulation is high cost of fish meal which reduces aquaculture production and the profit margin of fish farmers. According to Wang et al. (2006), reducing fish meal is the key to reducing feed cost for commercial fish farming and ensuring sustainability of this enterprise.

Animal manures are applied in an intensive culture to boost fish production through an increasing planktonic growth and releasing nitrogen and phosphorus, also providing an organic carbon through heterotrophic cycle 
(Mahboob and Al-Ghanim, 2014). In an attempt to further reduce the cost of fish feeds; this study has looked into the possibility of using dried poultry droppings as an alternative feed ingredient to fish meal. Little or no studies have been documented on the use of dried poultry droppings as an alternative feed ingredient to fish meal.

The aim of the hereby study was to investigate the effects of poultry droppings on microbial properties of fish feed and fish carcass, haematology and nutrient utilization of C. gariepinus.

\section{Materials and Methods}

\section{Sample collection}

Two hundred and twenty-five samples of $C$. gariepinus were purchased from a private farm in Ibadan, Oyo State. The fish samples were acclimatized in the laboratory for a period of two weeks and fed maintenance ration at $5 \%$ body weight before the commencement of feeding trial experiment.

\section{Experimental diet}

Fresh samples of poultry droppings were collected from the Poultry Unit of Department of Animal Science and Fisheries Management, Bowen University, Iwo, Osun State, Nigeria. The droppings were dried for a period of three weeks using solar drier of department of Physics and Solar, Bowen University, Iwo. The fish meal was partially and completely replaced by dried poultry droppings at $0 \%, 25 \%$, $50 \%, 75 \%$ and $100 \%$ inclusions. The dried poultry droppings (DPD) were incorporated with maize, fish meal (FM), groundnut cake (GNC), soya bean cake (SBC), bone meal $(\mathrm{BM})$, salt and fish premix. These mixtures (dried poultry droppings and feed ingredients) were pelleted into $0.8 \mathrm{~mm}$ pellets using $0.8 \mathrm{~mm}$ mincer. The pellets were sun dried to about $10 \%$ moisture contents. The dried pellets were stored inside air tight polythene bags. The formulated diets are shown in Table 1.

\section{Feeding trial experiment}

The feeding trial experiment was conducted for a period of 12 weeks. The fish samples were fed thrice daily (7.00 am, 12.00 noon and $6.00 \mathrm{pm}$ ) at $5 \%$ body weight. The experimental diets were adjusted fortnightly as the body weight changes.

\section{Experimental procedure}

The fish samples were allotted into fifteen fish per treatment and replicated thrice inside forty litres of experimental plastic bowls. Electric compressor (Shenzehe Company BS410) was used to aerate the water. The fish meal was partially and completely replaced by dried poultry droppings at $0 \%, 25 \%, 50 \%, 75 \%$ and $100 \%$ inclusions and was denoted T1, T2, T3, T4 and T5 respectively.

\section{Proximate composition of diets and carcass}

The proximate analysis of the fish carcass and experimental diets were determined before and after the experiment according to (AOAC, 2005).

\section{Isolation and identification of microorganisms}

The micro-organisms (bacteria and fungi) were isolated according to method described by Fawole and Oso (1985), Olutiola et al. (1991) and Brown (2005). Pure cultures of the isolates were maintained and stored on Nutrient agar slants at $4{ }^{\circ} \mathrm{C}$. The organisms were sub-cultured onto fresh slants every three months (90 days).

\section{Collection and determination of haematological profile}

Blood samples of the control and test fish were collected after the feeding trial into heparinised bottles by inserting 2 $\mathrm{ml}$ syringe needle into the posterior caudal vein. Packed Cell Volume (PCV) and haemoglobin $(\mathrm{Hb})$ concentration were analysed immediately after collection. Red blood cells (RBC) and white blood cells (WBC) were counted with Neubauer's improved haemocytometer using Hyem's and Turk's solution as a diluting fluid respectively. Mean Corpuscular Haemoglobin (MCH) and Mean Cell Volume (MCV) were calculated respectively using standard formula described by Dacie and Lewis (1984) and Joshi et al. (2002).

\section{Growth parameters}

The following growth parameters were calculated after the feeding trial experiment.

Mean weight gain was determined according to the formula described by Ishwata (1969). The mean weight gain was calculated by subtracting mean final weight $(\mathrm{g})$ from mean initial weight $(\mathrm{g})$.

The formula: $\left(\mathrm{LnW}_{2}-\mathrm{LnW}_{2}\right) / \mathrm{T}_{2}-\mathrm{T}_{1} \times 100$, described by Brown (1957) was used to calculate the SGR, where $\mathrm{W}_{2}$ and $\mathrm{W}_{1}$ are mean final weight and mean initial weight. $\mathrm{T}_{2}$ and $T_{1}$ are final day of the feeding trial and initial day of the feeding trial respectively.

Hepher (1988) determined FCR as total feed consumed (g) / weight gain by fish (g).

PER was determined according to the method of Zeiotoun et al. (1973): PER = Weight gain (g) / Protein intake.

Table 1. Formulated diet substituted with dried poultry droppings

\begin{tabular}{|c|c|c|c|c|c|}
\hline Ingredients & $0 \%$ & $25 \%$ & $50 \%$ & $75 \%$ & $100 \%$ \\
\hline Maize & 33.15 & 33.15 & 33.15 & 33.15 & 33.15 \\
\hline FM & 42.10 & 31.58 & 21.05 & 10.53 & - \\
\hline DPD & - & 10.52 & 21.05 & 31.57 & 42.10 \\
\hline Wheat offal & 7.34 & 7.34 & 7.34 & 7.34 & 7.34 \\
\hline SBC & 15.56 & 15.56 & 15.56 & 15.56 & 15.56 \\
\hline $\mathrm{BM}$ & 1.00 & 1.00 & 1.00 & 1.00 & 1.00 \\
\hline Salt & 0.25 & 0.25 & 0.25 & 0.25 & 0.25 \\
\hline Fish premix & 0.60 & 0.60 & 0.60 & 0.60 & 0.60 \\
\hline
\end{tabular}


462

\section{Statistical analysis}

The data collected were analyzed using Statistical Package for Social Sciences (SPSS), Version 11 (2001) and Statistical Analysis Software (SAS), Version 8 (2001). Duncan's Multiple Range Test was used to compare the differences among the means. The significant level was set at $5 \%$.

\section{Results and Discussion}

The proximate compositions of the dried poultry droppings used to substitute fish meal in this study are presented in Table 2 . The results showed that crude protein, crude fat, crude fibre, ash and moisture content values were analysed as: $40 \%, 11.74 \%, 2.54 \%, 2.70 \%$ and $7.11 \%$ respectively.

Similarly, the proximate compositions of the fish feed (Table 3) substituted with dried poultry droppings were determined. The crude protein value of T5 $(49.40 \%)$ increased significantly $\mathrm{p}<0.05$ than other treatments. The values recorded for crude fat showed a significant increase $(\mathrm{p}<0.05)$ in T5 (22.55\%). Crude fibre values varied significantly $(p<0.05)$ in T5 $(7.34 \%)$ compared with other treatments. Statistics further indicated that ash $(6.85 \%)$ and moisture $(12.92 \%)$ in T5 were significantly different at $\mathrm{p}<0.05$ than other treatments.

Proximate compositions of the fish carcass (Table 4) were analysed. The results clearly indicated that crude protein values of the fish carcass showed a high level of significance $(\mathrm{p}<0.05)$ in T5 $(31.53 \%)$. The crude fat value recorded in T5 (4.82\%) was significantly higher than other treatments. The results of crude fibre revealed that T5 $(5.83 \%)$ was significantly different $(\mathrm{p}<0.05)$ compared to other treatments. The values recorded for ash revealed that T2 (1.48\%) varied significantly than other treatments. Moisture contents in this study showed that T5 (85.47\%) was significantly higher $(p<0.05)$ than other treatments. To certain extent, it was very evident that the level of dried poultry inclusions reflected in fish feed and fish carcass compositions. Summarily, increased dried poultry droppings inclusions reflected an upward trend in proximate compositions of the fish feed and fish carcass.

The microbial properties of the dried poultry droppings investigated are shown in Table 5. The values recorded for Total Viable count (TVC), Total Coliform count (TCC) and Total Fungal count (TFC) were $11.8 \times 10^{5} \mathrm{cfu} / \mathrm{g}$, $0.8 \times 10^{5} \mathrm{cfu} / \mathrm{g}$ and $0.7 \times 10^{5} \mathrm{cfu} / \mathrm{g}$ respectively. Chicken droppings is a source of human pathogens such as Salmonella, Campylobacter jejuni, Listeria monocytogenes that can potentially contaminate the environment and are frequently known to be associated with food borne disease outbreaks (Chinivasagam et al., 2010). In the current study, the TVC and TCC showed a heavy contamination because these wastes were contaminated with ubiquitous microorganisms. Coliforms are a part of the normal micro flora of the animal digestive tract and some of these enteric bacteria may get dispensed into the environment (Kemoi, 2012). Further investigation conducted on the fish feeds (Table 6) to show the occurrence of microbes revealed that TVC in T5 $\left(13.0 \times 10^{5} \mathrm{cfu} / \mathrm{g}\right)$ was significantly different $(p<0.05)$ compared to other treatments. The values of TCC $\left(0.80 \times 10^{5} \mathrm{cfu} / \mathrm{g}\right)$ and TFC $\left(0.70 \times 10^{5} \mathrm{cfu} / \mathrm{g}\right)$ in T5 showed a significant increase $\mathrm{p}<0.05$. The values recorded during the investigation showed that microbial load increased in the fish feed with increase in the addition of the

Table 2. Proximate composition of the poultry droppings

\begin{tabular}{cc}
\hline Parameters & Value \\
\hline Crude protein (\%) & 40.00 \\
Crude fat (\%) & 11.74 \\
Crude fibre (\%) & 2.54 \\
Ash (\%) & 2.70 \\
Moisture content (\%) & 7.11 \\
\hline
\end{tabular}

Table 3. Proximate composition of the feed

\begin{tabular}{cccccc}
\hline Parameters & T1 & T2 & T3 & T4 & T5 \\
\hline Crude protein (\%) & $44.10^{\mathrm{c}}$ & $43.15^{\mathrm{c}}$ & $46.35^{\mathrm{b}}$ & $48.30^{\mathrm{a}}$ & $49.40^{\mathrm{a}}$ \\
Crude fat (\%) & $14.65^{\mathrm{d}}$ & $13.15^{\mathrm{c}}$ & $16.40^{\mathrm{c}}$ & $19.45^{\mathrm{b}}$ & $22.55^{\mathrm{a}}$ \\
Crude fibre (\%) & $6.80^{\mathrm{b}}$ & $6.35^{\mathrm{c}}$ & $7.15^{\mathrm{a}}$ & $7.19^{\mathrm{a}}$ & $7.34^{\mathrm{a}}$ \\
Ash (\%) & $5.21^{\mathrm{d}}$ & $4.95^{\mathrm{c}}$ & $5.49^{\mathrm{c}}$ & $6.03^{\mathrm{b}}$ & $6.85^{\mathrm{a}}$ \\
Moisture content (\%) & $9.30^{\mathrm{c}}$ & $9.65^{\mathrm{d}}$ & $10.25^{\mathrm{c}}$ & $12.43^{\mathrm{b}}$ & $12.92^{\mathrm{a}}$ \\
\hline
\end{tabular}

Mean with the same superscript are not significantly different

Table 4. Proximate composition of the fish carcass

\begin{tabular}{|c|c|c|c|c|c|}
\hline Parameters & $\mathrm{T} 1$ & $\mathrm{~T} 2$ & T3 & $\mathrm{T} 4$ & $\mathrm{~T} 5$ \\
\hline Crude protein (\%) & $24.28^{\mathrm{e}}$ & $25.63^{d}$ & $27.37^{c}$ & $28.46^{b}$ & $31.53^{\mathrm{a}}$ \\
\hline Crude fat (\%) & $3.03 \mathrm{c}$ & $3.48^{\mathrm{b}}$ & $3.65^{b}$ & $4.63^{\mathrm{a}}$ & $4.82^{\mathrm{a}}$ \\
\hline Crude fibre (\%) & $4.65^{b}$ & $4.13^{c}$ & $5.11^{\mathrm{a}}$ & $5.29^{\mathrm{a}}$ & $5.83^{\mathrm{a}}$ \\
\hline Ash (\%) & $1.21^{\mathrm{c}}$ & $1.48^{\mathrm{a}}$ & $1.40^{\mathrm{ba}}$ & $1.33^{\mathrm{b}}$ & $1.36^{\mathrm{b}}$ \\
\hline Moisture content (\%) & $74.72^{\mathrm{d}}$ & $75.45^{d}$ & $81.08^{c}$ & $82.87^{b}$ & $85.47^{\mathrm{a}}$ \\
\hline
\end{tabular}

Mean with the same superscript are not significantly different 
Table 5. Microbial properties of the poultry droppings

\begin{tabular}{cc}
\hline Parameters & Value $(\mathrm{cfu} / \mathrm{g})$ \\
\hline TVC & $11.8 \times 10^{5}$ \\
TCC & $0.8 \times 10^{5}$ \\
TFC & $0.7 \times 10^{5}$ \\
\hline Mean with the same superscript are not significantly different
\end{tabular}

Table 6. Microbial properties of the feed

\begin{tabular}{ccclll}
\hline Parameters & T1 $(\mathrm{cfu} / \mathrm{g})$ & T2 $(\mathrm{cfu} / \mathrm{g})$ & $\mathrm{T} 3(\mathrm{cfu} / \mathrm{g})$ & $\mathrm{T} 4(\mathrm{cfu} / \mathrm{g})$ & $\mathrm{T} 5(\mathrm{cfu} / \mathrm{g})$ \\
\hline TVC & $8.4 \times 10^{3 \mathrm{bc}}$ & $9.4 \times 10^{3 \mathrm{ba}}$ & $10.0 \times 10^{3 \mathrm{ba}}$ & $12.0 \times 10^{3 \mathrm{ba}}$ & $13.0 \times 10^{3 \mathrm{a}}$ \\
TCC & $0.40 \times 10^{3 \mathrm{c}}$ & $0.50 \times 10^{3 \mathrm{~d}}$ & $0.70 \times 10^{3 \mathrm{c}}$ & $0.90 \times 10^{3 \mathrm{a}}$ & $0.80 \times 10^{\mathrm{ba}}$ \\
TFC & $0.20 \times 10^{\mathrm{c}}$ & $0.30 \times 10^{3 \mathrm{bc}}$ & $0.40 \times 10^{\mathrm{b}}$ & $0.40 \times 10^{3 \mathrm{~b}}$ & $0.70 \times 10^{3 \mathrm{a}}$ \\
\hline
\end{tabular}

Mean with the same superscript are not significantly different

dried poultry droppings. El-Jalil et al. (2008) investigated the microbiological and chemical properties of poultry waste manure after lactic acid fermentation and reported that dried droppings were heavily contaminated with microorganisms.

The microbial properties of the fish carcass are shown in Table 7. The results showed that TVC was significantly higher in T5 $\left(2.72 \times 10^{5} \mathrm{cfu} / \mathrm{g}\right)$. The highest TCC value was recorded in T5 $\left(0.33 \times 10^{5} \mathrm{cfu} / \mathrm{g}\right)$. Statistics showed that T5 varied significantly $(\mathrm{p}<0.05)$ than other treatments. The highest TFC values recorded in T3 and T5 increased significantly than other treatments. The high level of microbes recorded in T5 could be attributed to the high level of microbes ingested in the fish feed. Different bacteria associated with fish and their intestines have been documented e.g. Flavobacterium columnare in fish kidney (Bernardet, 1989); Streptococcus (Eldar et al., 1994); Aeromonas (Huys et al., 1997); Carnobacter from fish intestines (Ringø, 2008).

The haematological parameters of Clarias gariepinus fed diet substituted with dried poultry droppings. The PCV ranged between $20.48 \%$ (T5) and $43.00 \%$ (T1) (Table 8). The results showed that T1 was significantly higher $(p<0.05)$ than other treatments. The values of haemoglobin recorded ranged between $6.12 \mathrm{~g} / \mathrm{dl}(\mathrm{T} 5)$ and $11.23 \mathrm{~g} / \mathrm{dl}(\mathrm{T} 1)$. The highest value of $\mathrm{RBC}$ was recorded in T2 $\left(3.77 \times 10^{6} / \mathrm{mm}^{3}\right)$ and the lowest was T5 $(1.12$ $\times 10^{6} / \mathrm{mm}^{3}$ ). The WBC was within a range of 14.40 $\times 10^{6} / \mathrm{mm}^{9}$ (T1) and $15.95 \times 10^{6} / \mathrm{mm}^{9}$ (T5). The haematological parameters further showed that $\mathrm{MCH}$ ranged from $26.84 \mathrm{pg}$ (T2) to $54.64 \mathrm{pg}$ (T5). For MCV, a significant increase $(\mathrm{p}<0.05)$ was obtained in T5 $(182.86$ $\mathrm{fl}$ ) when compared with other treatments.

Haematological studies are useful in the diagnosis of many diseases as well as investigation of the extent of damage to blood (Onyeyili et al., 1992; Togun et al., 2007). A reduced red blood cell count implies a reduction in the level of oxygen that would be carried to the tissues as well as the level of carbon dioxide returned to the lungs (Ugwuene, 2011; Isaac et al., 2013; Soetan et al., 2013). Haemoglobin has the physiological function of transporting oxygen to tissues of the animal for oxidation of ingested food so as to release energy for the other body functions, as well as transport carbon dioxide out of the body of animals (Ugwuene, 2011; Omiyale et al., 2012; Isaac et al., 2013; Soetan et al., 2013). Packed Cell Volume (PCV) is the percentage (\%) of red blood cells in blood
(Purves, Sadava, Orians and Heller, 2003). According to Isaac et al. (2013) PCV is involved in the transport of oxygen and absorbed nutrients. Increased PCV shows a better transportation.

The decrease obtained in PCV, RBC and $\mathrm{Hb}$ values in the test fishes was consistent with the observation of Ayoola (2011) who fed C. gariepinus fish with poultry hatchery waste. Decrease in RBC and haemoglobin values in $C$. garipienus fed with poultry hatchery waste in this study was similar to the observations of the research conducted by Gill and Pant (1981) in C. batrachus exposed to different toxicants.

A significant reduction in $\mathrm{RBC}$ obtained from $\mathrm{T} 5$ (1.12) in this study may however be due to its reduced ability to transport Oxygen due to the high concentration of the toxicant. The anaemic status may also be as a result of inhibition of erythropoiesis and haemosynthesis consequent to an increase in the rate of erythrocytes destruction in haemopoietic organs. Buckley et al. (1976) adjudged that prolonged reduction in $\mathrm{Hb}$ content is deleterious to oxygen transport and degeneration of the erythrocytes which could be ascribed as pathological conditions in fishes exposed to toxicants.

The major functions of the white blood cell and its differentials are to fight infections, defend the body by phagocytosis against invasion by foreign organisms and to produce or at least transport and distribute antibodies in immune response. Thus, animals with low white blood cells are exposed to high risk of disease infection, while those with high counts are capable of generating antibodies in the process of phagocytosis and have high degree of resistance to diseases (Soetan et al., 2013) and enhance adaptability to local environmental and disease prevalent conditions (Kabir et al., 2011; Iwuji and Herbert, 2012; Okunlola et al., 2012; Isaac et al., 2013). WBC count obtained in test fish T3 and T5 were significantly higher than that of the control and T2. Increase in WBC can be correlated with an increase in antibody production which helps in survival and recovery of fish exposed to toxicants as observed by Tiago et al. (2008) in Brycon amazonica exposed to low concentrations of phenol in the laboratory. In the present study, the significant increase in WBC count indicate hypersensitivity of these cells to dried poultry droppings and the changes may be due to immunological reaction to produce more antibodies to combat the stress induced through exposure to the dried poultry wastes. 
464

Table 7. Microbial properties of the fish carcass

\begin{tabular}{clllll}
\hline Parameters & T1 $(\mathrm{cfu} / \mathrm{g})$ & T2 $(\mathrm{cfu} / \mathrm{g})$ & T3 $(\mathrm{cfu} / \mathrm{g})$ & T4 $(\mathrm{cfu} / \mathrm{g})$ & T5 $(\mathrm{cfu} / \mathrm{g})$ \\
\hline TVC & $1.62 \times 10^{3 \mathrm{c}}$ & $1.70 \times 10^{3 \mathrm{c}}$ & $2.43 \times 10^{3 \mathrm{ba}}$ & $2.33 \times 10^{5 \mathrm{~b}}$ & $2.72 \times 10^{5 \mathrm{a}}$ \\
TCC & $0.13 \times 10^{5 \mathrm{c}}$ & $0.17 \times 10^{5 \mathrm{c}}$ & $0.27 \times 10^{3 \mathrm{ba}}$ & $0.23 \times 10^{3 \mathrm{~b}}$ & $0.33 \times 10^{3 \mathrm{a}}$ \\
TFC & $0.10 \times 10^{5 \mathrm{c}}$ & $0.10 \times 10^{5 \mathrm{c}}$ & $0.20 \times 10^{5 \mathrm{a}}$ & $0.13 \times 10^{5 \mathrm{ba}}$ & $0.20 \times 10^{3 \mathrm{a}}$ \\
\hline
\end{tabular}

Mean with the same superscript are not significantly different

Table 8. Haematological parameters of the test and control fish fed with dried poultry waste for 12 weeks

\begin{tabular}{ccccccc}
\hline Sample & $\mathrm{Hb}(\mathrm{g} / \mathrm{l})$ & $\mathrm{PCV}(\mathrm{g} / \mathrm{l})$ & $\mathrm{RBC}\left(10^{6} / \mathrm{mm}^{3}\right)$ & $\mathrm{WBC}\left(10^{9} / \mathrm{l}\right)$ & $\mathrm{MCH}(\mathrm{pg})$ & $\mathrm{MCV}(\mathrm{Fl})$ \\
\hline T1 & $11.23 \pm 5.03^{\mathrm{a}}$ & $43.00 \pm 0.01^{\mathrm{a}}$ & $3.52 \pm 0.1^{\mathrm{a}}$ & $14.40 \pm 2.52^{\mathrm{bc}}$ & $31.90 \pm 5.38^{\mathrm{b}}$ & $122.16 \pm 16.44^{\mathrm{b}}$ \\
T2 & $10.12 \pm 18.58^{\mathrm{ab}}$ & $35.67 \pm 0.05^{\mathrm{ab}}$ & $3.77 \pm 0.4^{\mathrm{a}}$ & $14.77 \pm 2.00^{\mathrm{b}}$ & $26.84 \pm 10.59^{\mathrm{cd}}$ & $94.61 \pm 31.22^{\mathrm{d}}$ \\
T3 & $9.53 \pm 11.53^{\mathrm{b}}$ & $29.33 \pm 0.03^{\mathrm{c}}$ & $2.86 \pm 0.3^{\mathrm{b}}$ & $15.75 \pm 2.64^{\mathrm{a}}$ & $33.32 \pm 18.81^{\mathrm{b}}$ & $102.55 \pm 0.57^{\mathrm{c}}$ \\
T4 & $9.40 \pm 19.28^{\mathrm{b}}$ & $32.30 \pm 0.05^{\mathrm{b}}$ & $3.23 \pm 0.2^{\mathrm{ab}}$ & $15.67 \pm 3.51^{\mathrm{ab}}$ & $29.10 \pm 5.37^{\mathrm{c}}$ & $100.00 \pm 16.44^{\mathrm{c}}$ \\
T5 & $6.12 \pm 5.13^{\mathrm{c}}$ & $20.48 \pm 0.01^{\mathrm{d}}$ & $1.12 \pm 0.05^{\mathrm{c}}$ & $15.95 \pm 2.51^{\mathrm{a}}$ & $54.64 \pm 2.96^{\mathrm{a}}$ & $182.86 \pm 9.29^{\mathrm{a}}$ \\
\hline Mean with the same superscript are not significantly different & & &
\end{tabular}

Table 9. Nutrient utilization of diets fed Clarias gariepinus

\begin{tabular}{cccccc}
\hline Parameters & T1 & T2 & T3 & T4 & T5 \\
\hline MIW $(\mathrm{g})$ & 20.05 & 20.09 & 20.07 & 20.08 & 20.05 \\
MFW (g) & 41.78 & 49.82 & 39.23 & 46.27 & 38.04 \\
MWG $(\mathrm{g})$ & $21.73^{\mathrm{b}}$ & $29.73^{\mathrm{a}}$ & $19.16^{\mathrm{bc}}$ & $26.19^{\mathrm{ab}}$ & $17.99^{\mathrm{c}}$ \\
SGR & $0.16^{\mathrm{b}}$ & $0.30^{\mathrm{a}}$ & $0.06^{\mathrm{c}}$ & $0.22^{\mathrm{ab}}$ & $0.03^{\mathrm{d}}$ \\
FCR & $0.10^{\mathrm{ab}}$ & $0.09^{\mathrm{a}}$ & $0.10^{\mathrm{ab}}$ & $0.09^{\mathrm{a}}$ & $0.11^{\mathrm{b}}$ \\
PER & $0.28^{\mathrm{ab}}$ & $0.31^{\mathrm{a}}$ & $0.26^{\mathrm{b}}$ & $0.30^{\mathrm{a}}$ & $0.25^{\mathrm{b}}$ \\
\hline
\end{tabular}

Mean with the same superscript are not significantly different

The significant increase $(\mathrm{p}<0.05)$ observed for MCV and $\mathrm{MCH}$ in test fish T5 compared to the control may be attributed to direct or feedback responses of structural damage to red blood cell membranes resulting in haemolysis and impairment in haemoglobin synthesis and stress-related release of red blood cells from the spleen and hypoxia, induced by exposure to toxicant (Shah, 2006).

The growth and nutrient utilization of fish fed dried poultry droppings are presented in Table 9. During the feeding trial experiment, there was a significant increase $\mathrm{p}<0.05$ in weight gain in T2 compared with other treatments. Unfortunately, T5 which had the highest percentage of dried poultry droppings had the least weight gain recorded. Hypothetically, it would be expected that T5 which had the highest dried poultry droppings would give the best weight gain. This trend could be traced to the highest values of TVC, TCC and TFC and lowest values of haematological parameters such as $\mathrm{Hb}, \mathrm{PCV}$ and $\mathrm{RBC}$ recorded in $\mathrm{T} 5$.

\section{Conclusions}

The expected trend of growth and nutrient utilization in fish can be altered when the feed components are loaded with pathogens such as fungi and bacteria. Haematological parameters reflect the health status of the fish. It is assumed that fish grows and utilize nutrients in their diets when they are having the right range values which declared a fish to be healthy. The range values of microbial and haematological properties in $\mathrm{T} 5$ recorded in the current study could not trigger any significant growth in the fish.

\section{Acknowledgements}

The authors acknowledge the Committee of Research and Learned Conferences Funds of Bowen University, Iwo, Osun State, Nigeria, for providing research grant (REF: BUI/CRLCF/01/11) used to carry out this study.

\section{References}

Antolović N, Kožul V, Antolović M and Bolotin J (2012). Effects of partial replacement of fish meal by soybean meal on growth of juvenile saddled bream (Sparidae). Turkish Journal of Fisheries and Aquatic Sciences 12:247-252.

AOAC (2005). International official methods of analysis (18 $\left.18^{\text {th }} \mathrm{Ed}\right)$. AOAC International, Gaithersburg, MD.

Ayinla OA, Bekibele DO (1992). Fish feed and nutrition in Nigeria: the preferred state of knowledge and the ways forward. NIOMR Technical PaperNo 83.

Ayoola SO (2010). Haematological characteristics of Clarias gariepinus (Buchell, 1822) juveniles fed on poultry hatchery waste. AmericanEurasian Journal of Toxicological Sciences 2(4):190-195.

Bernardet JF (1989). Flexibacter columnaris: first description in France and comparison with bacterial strains from other origins. Diseases of Aquatic Organisms 6:37-44.

Brown AE (2005). Benson's microbiological applications ( $\left.9^{\text {th }} \mathrm{Ed}\right)$. McGrawHill, New Yorkpp 57-59.

Brown ME (1957). Experimental studies on growth. The physiology of Fishes 1:360-400.

Chinivasagam HN, Redding M, Runge G, Blackall PJ (2010). Presence and incidence of foodborne pathogens in Australian chicken litter. British PoultryScience 51(3):311-318. 
Dacie JV, Lewis SM (1984). Practical haematology (6 $6^{\text {th }}$ Ed). ELBS and Churchill,Livingston.

Eldar A, Bejerano Y, Bercovier H (1994). Streptococcusshiloi and Streptococcus difficile: two new Streptococcal species causing meningoencephalitis in fish. Current Microbiology 28:139-143.

El-jalil MH, Zinedine A, Faid M (2008). Some microbiological and chemical properties of poultry waste manure after lactic acid fermentation. International Journal of Agriculture and Biology 10(4):405-411.

Fawole MO, Oso BA (1985). Laboratory manual of microbiology. Spectrum books limited, Ibadan, Nigeria pp 15-21.

Gill IS, Pant JC (1981). Effect of sublethal concentrations of mercury in a teleost Puntius conchonius biochemical and haematological responses. Indian Journal Experimental Biology 9:571-573.

Hepher B (1988). Nutrition of pond fishes. Cambridge University Press. UK.

Huys G, Kämpfer P, Altwegg M, Kersters I, Lamb A, Coopman R, LüthyHottenstein J (1997). Aeromonas popoffii sp. nov., a mesophilic bacterium isolated from drinking waterproduction plants and reservoirs. International Journal of Systematic Bacteriology 47:1165-1171.

Isaac LJ, Abah G, Akpan B, Ekaette IU (2013). Haematological properties of different breeds and sexes of rabbits. Proceedings of the 18th Annual Conference of Animal Science Association of Nigeria pp 2427.

Ishwata N (1969). Ecological studies on the feeding of fishes. Frequency of feeding and growth. Bulletin of the Japanese Society for the Science of Fish 35:985-989.

Iwuji TC, Herbert U (2013). Haematological and serum biochemical characteristics of rabbit bucks fed diets containing garcimiola kola seed meal, Proceedings of 37th Annual Conference of Nigerian Society for Animal Production 2012pp 87-89.

Jatta S, Sigurgeirsson O (2013). The effects of substituting fishmeal with rapeseed meal at three protein levels on growth and body composition of Nile Tilapia fingerlings (Oreochromis niloticus). UNU-Fisheries Training Programme.

Joshi PK, Bose M, Harish D (2002). Haematological changes in the blood of Clariasbatrachus exposed to mercuric chloride. Eco toxicological Environmental Monitoring 12(2):119-122.

Kabir M, Akpa GN, Nwagu BI, Adeyinka IA, Bello UI (2011). Sexual dimorphism, breed and age characteristics of rabbits in Zaria, Nigeria. Proceedings of the 16th Annual Conference of Animal Science Association of Nigeriapp 133-137.

Kemoi EK (2012). Isolation and characterisation of yeast from Gallus gallus droppings in Kabigeriet Village, Olenguruone. MSc Thesis. Kenyatta University.

Kushwaha MP (2013). Replacement of fish meal by soybean (Glycine max) in the formulation of fish feed ingredients essential for immunestimulation and growth performance of carps. International Journal of Fauna and Biological Studies 1(2):35-38.

Mahboob S, Al-Ghanim KA (2014). Effect of poultry droppings on the primary productivity and growth performance of major carps in polyculture system. Pakistan Journal ofZoology 46(3):799-803.
Okunlola DO, Olorunisomo AO, Aderinola AO, Agboola AS, Omole OG (2012). Haematology and serum quality of red Sokoto goats fed Baobab (Adansonia digitata) fruit meal as supplement to guinea grass (Panicum maximum). Proceedings of the 17th Annual Conference of Animal Science Association of Nigeria pp 427-433.

Olutiola PO, Famurewa O, Sonntag HG (1991). An introduction to general microbiology: a practical approach. GmbH-Heidelberg, Germany.

Omiyale CA, Yisa AG, Ali-Dunkrah LA (2012). Haematological characteristics of Yankasa sheep fed fonio (Digitaria iburua) straw based diets. Proceedings of 37th Annual Conference of Nigerian Society for Animal Production pp 87-89.

Onyeyili PA, Egwu GO, Jibike GI, Pepple DJ, Ohaegbulam JO (1992). Seasonal variation in haematological indices in the grey-breasted guinea fowl (Numida mealagris Gallata pallas). Nigerian Journal of Animal Production 18(2):108-110.

Ringø E (2008). The ability of Carnobacteria isolated from fish intestine to inhibit growth of fish pathogenic bacteria: a screening study. Aquaculture Research 39(2):171-180.

Shah SL (2006). Haematological parameters in Tinca tinca after short term exposure to lead. Journal of Applied Toxicology 26(3):223-266.

Soetan KO, Akinrinde AS, Ajibade TO (2013). Preliminary studies on the haematological parameters of cockerels fed raw and processed guinea corn (Sorghum bicolor). Proceedings of 38th Annual Conference of Nigerian Society for Animal Production pp 49-52.

Tiago SFH, Ive MA, Iwana GK, Johnson SC, Moracs G, Afonson LOB. (2008). Impairment of the stress response in matrinxa juvenile Brycon amazonicus exposed to low concentration of phenol. Comparative Biochemistry and Physiology 147:416-423.

Togun VA, Oseni BSA, Ogundipe JA, Arewa TR, Hammed AA, Ajonijebu DC, Mustapha F (2007). Effects of chronic lead administration on the haematological parameters of rabbits - a preliminary study. Proceedings of the 41st Conferences of the Agricultural Society of Nigeria pp 341.

Ugwuene MC (2011). Effect of dietary palm kernel meal for maize on the haematological and serum chemistry of broiler turkey. Nigerian Journal of Animal Science 13:93-103.

United Nations University (2013). Fisheries Training Programme 1-2.

Vancanneyt M, Janssen P, Kersters K (1997). Aeromonas popoffii sp. nov., a mesophilic bacterium isolated from drinking water production plants and reservoirs. International Journal of Systematic Bacteriology 47:1165-1171.

Wang Y,Kong L, Li C, Bureau DP (2006). Effect of replacing fish meal with soybean meal on growth, feed utilization and carcass composition of cuneate drum (Nibea miïhthioides). Aquaculture 261:1307-1313.

Zeiotoun IH, Jack I, Halver JF, Ulray DF (1973). Influence of salinity on protein requirements. Journal of the Fisheries Board of Canada 30(12):1867-1873. 